\title{
ANALISA KESALAHAN FONETIK PADA BUKU "PERCAKAPAN BAHASA MANDARIN SEHARI-HARI LENGKAP LANGSUNG BISA"
}

\author{
Sudono Noto Pradono \\ Politeknik NSC Surabaya \\ Email: sudono32@yahoo.com
}

\begin{abstract}
Abstrak
Tujuan dari penulisan artikel ini adalah untuk menganalisa kesalahan fonetik pada buku "Percakapan Bahasa Mandarin Sehari-hari Lengkap Langsung Bisa" tersebut. Didalam melakukan analisa kesalahan ini, metode penelitian yang dikerjakan oleh penulis adalah melakukan pengamatan terhadap fonetik-fonetik dari karakter-karakter bahasa Mandarin yang terdapat dalam buku tersebut. Penulis menyimpulkan adanya kesalahan-kesalahan fonetik yang ada dalam buku yang berjudul "Percakapan Bahasa Mandarin Sehari-hari Lengkap Langsung Bisa", hal tersebut mungkin terjadi karena penulis dari buku tersebut kurang teliti terhadap fonetik-fonetik dari karakter-karakter Bahasa Mandarin.
\end{abstract}

Kata kunci: fonetik, nada, karakter.

\begin{abstract}
The purpose of writing this article is to analyze phonetic errors in the book "Percakapan Bahasa Mandarin Sehari-hari Lengkap Langsung Bisa". In conducting this error analysis, the research method undertaken by the writer is to observe the phonetics of the Chinese characters in the book. The writer concludes that there are phonetic errors in the book entitled "Percakapan Bahasa Mandarin Sehari-hari Lengkap Langsung Bisa", this may occur because the author of the book is not careful about the phonetics of Chinese characters.
\end{abstract}

Keywords: phonetic, tone, character.

\section{PENDAHULUAN}

Dengan semakin eratnya hubungan antara Tiongkok dengan Indonesia baik dalam bidang perdagangan, perindustrian, pariwisata dan lain sebagainya, hal ini membuat semakin banyak orang Indonesia yang tertarik untuk mempelajari bahasa Mandarin. Oleh sebab itu, banyak buku bahasa Mandarin yang telah diterbitkan. Salah satunya adalah buku yang berjudul "Percakapan Bahasa Mandarin Sehari-hari Lengkap Langsung Bisa". Dalam kata pengantar pada buku tersebut dituliskan bahwa buku bahasa Mandarin ini dikhususkan untuk pembelajar tingkat dasar, menengah dan mahir tapi tidak menutup kemungkinan dipakai oleh pembelajar bahasa Mandarin pemula baik itu siswa SD, SMP, SMA, kalangan mahasiswa dan umum.

Adapun data dari buku tersebut adalah sebagai berikut: a) judul: "Percakapan Bahasa Mandarin Sehari-hari Lengkap Langsung Bisa"; b) penulis: Muryani J Semitha; c) editor: Budi; d) cetakan ke-1, 2016; d) penerbit: Pusat Kajian Bahasa, 
Yogyakarta; e) ISBN: 978-602-6380-22-7; f) total halaman: 196 halaman.

Setelah penulis membaca buku tersebut, penulis mendapatkan kesalahan pada fonetik dari karakter bahasa Mandarin. Oleh sebab itu, tujuan dari penulisan artikel ini adalah untuk menganalisa kesalahan fonetik pada buku "Percakapan Bahasa Mandarin Sehari-hari Lengkap Langsung Bisa" tersebut.

\section{KAJIAN LITERATUR}

Menurut Li dan Li (1999) fonetik bahasa Mandarin mempunyai 21 声母 (shēng $m u$ ) atau 21 konsonan awal dan 39 韵母 (yùn $m u$ ) atau 39 vokal majemuk. Selain itu, bahasa Mandarin juga merupakan bahasa yang mempunyai nada. Adapun nada-nada di dalam bahasa Mandarin tersebut oleh Huang dan Liao (2004) digambarkan sebagai berikut:

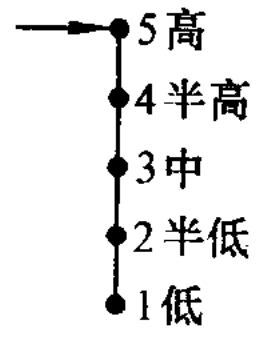

阴平 55

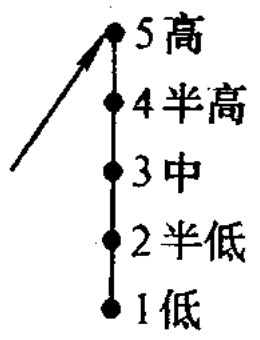

阳平 35

(sumber: Huang dan Liao, 2004, hal. 80)

Keempat nada tersebut dijelaskan sebagai berikut:

1. 阴平 (yīn píng) atau nada kesatu, tinggi dan rata, dari tingkat 5 ke tingkat 5 , misalnya a) 高 (gāo) yang artinya "tinggi”; b) 飞 (fēi) yang artinya "terbang"; c) 天 (tiān) yang artinya "langit".

2. 阳平 (yáng píng) atau nada kedua, dari tingkat 3 naik ke tingkat 5, misalnya a) 来 (lái) yang artinya “datang”; b) 回 (huî) yang artinya "pulang, kembali"; c) 忙 (máng) yang artinya "sibuk".

3. 上声 (shăng shēng) atau nada ketiga, dari tingkat 2 turun ke tingkat 1 lalu naik lagi ke tingkat 4, misalnya a) 好( hăo) yang artinya "baik"; b) 马 (mă) yang artinya "kuda"; c) 敢 (găn) yang artinya "berani”.

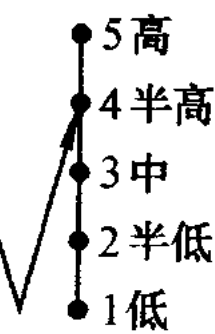

上声 214

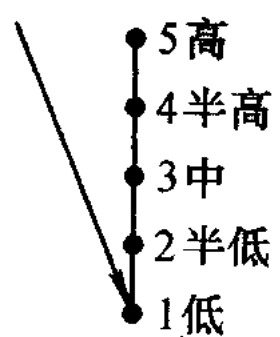

去声 51
4. 去声 (qù shēng) atau nada keempat, dari tingkat 5 turun ke tingkat 1, misalnya a) 事 (shì) yang artinya "hal, urusan, persoalan"; b) 痛 (tòng) yang artinya “nyeri, sakit”; c) 易 (yì) yang artinya "mudah, gampang".

Selain keempat nada tersebut di atas, dalam bahasa Mandarin juga mempunyai nada ringan, nada ringan tersebut diucapkan dengan ringan dan pendek, dimana dalam penulisannya tidak ada tandanya (Kang dan Lai, 2000), contohnya 爸爸 (bàba), 他们 (tāmen), 什么 (shénme).

Menurut Kang dan Lai (2000), fungsi dari nada tersebut adalah untuk membedakan arti, misalnya sebagai berikut:

nada kesatu : 肤 ( $f \bar{u})$ yang artinya adalah "kulit". 


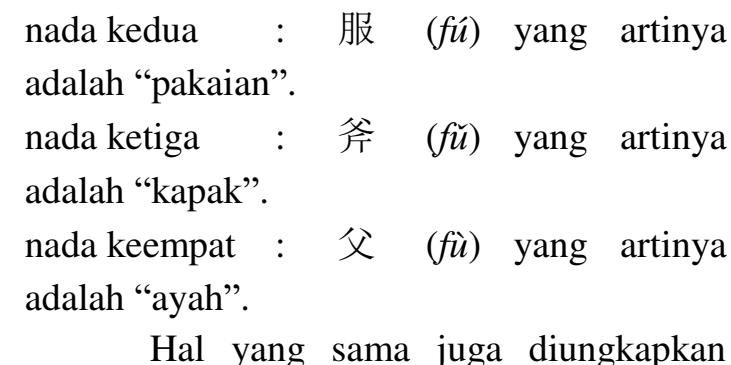
oleh Ross dan Jing-heng (2006), mereka menyatakan bahwa ada empat nada dalam bahasa Mandarin dan satu nada ringan. Nada tersebut mempunyai fungsi untuk membedakan arti, misalnya pada karakterkarakter Mandarin berikut ini:

$$
\begin{aligned}
& \text { nada kesatu : 妈 (mā) yang artinya } \\
& \text { adalah "ibu". } \\
& \text { nada kedua : 麻 (má) yang artinya } \\
& \text { adalah "mati rasa". } \\
& \text { nada ketiga : 马 (mă) yang artinya } \\
& \text { adalah "kuda". } \\
& \text { nada keempat ： 骂 (mà) yang artinya } \\
& \text { adalah "memaki". } \\
& \text { nada ringan : 吗 (ma) yang artinya } \\
& \text { adalah "apakah". } \\
& \text { Dari contoh-contoh diatas dapat } \\
& \text { ditarik kesimpulan bahwa meskipun lafalnya }
\end{aligned}
$$

\section{METODE PENELITIAN}

Penulis telah mempelajari buku yang berjudul "Percakapan Bahasa Mandarin Sehari-hari Lengkap Langsung Bisa". Dalam buku tersebut terdapat 21 pelajaran, dimana dalam setiap pelajaran ada a) Membaca; b) Percakapan; c) Menjodohkan Dengan Menarik Garis; d) Menulis Aksara Han (karakter Mandarin); e) Kosakata Baru. Didalam melakukan analisa kesalahan ini, metode penelitian yang dikerjakan oleh penulis adalah melakukan pengamatan terhadap fonetik-fonetik dari karakterkarakter bahasa Mandarin yang terdapat dalam buku tersebut.

\section{HASIL DAN PEMBAHASAN}

Kesalahan-kesalahan fonetik yang penulis temukan dalam buku "Percakapan Bahasa Mandarin Sehari-hari Lengkap Langsung Bisa" diuraikan sebagai berikut:

\section{Halaman 15 dan 16}

\section{早上好!}

Zāoshàng hăo!

Selamat pagi!

晚上好!

Wănshàng hăo!

Selamat malam!

Fonetik dari karakter “上” tertulis "shàng” dalam nada keempat. Seharusnya, fonetik dari karakter “上” tertulis "shang” dalam nada ringan. Menurut Pan dan Chen (1995 : 1107), fonetik dari “早上” adalah "zāoshang” yang artinya "pagi". Sedangkan menurut Shendingweiyuanhui (2012 : 1341), fonetik dari “晚上” adalah “wănshang” yang artinya "malam". Oleh sebab itu, penulisan fonetik yang benar adalah sebagai berikut:

早上好!

Zāoshang hăo!

晚上好!

Wănshang hăo!

\section{Halaman 23}

我们一家人相亲相爱。

Wǒmen yī jiā rén xiāng qīn xiāng ài.

Kami sekeluarga saling mengasihi.

Fonetik dari karakter "一" tertulis " $y \overrightarrow{\mathrm{y}}$ " dalam nada kesatu. Menurut Cheung (1994 : 61), bila karakter "一” diikuti oleh karakter yang mempunyai nada kesatu, maka fonetik dari karakter "一” berubah menjadi nada keempat. Dalam hal ini, karakter “家” tertulis “jiâ" dalam nada kesatu, maka fonetik dari 
karakter "一" seharusnya tertulis "yì" dalam nada keempat. Oleh sebab itu, penulisan fonetik yang benar adalah sebagai berikut: 我们一家人相亲相爱。

Wǒmen yì jiā rén xiāng qīn xiāng ài.

\section{Halaman 35}

。。有小小的眼睛, 有长长的头发。

... yǒu xiăoxiao de yănjīng, yǒu chángchang de tóufã.

...mempunyai mata yang kecil, mempunyai rambut yang panjang.

Fonetik dari “眼睛” tertulis “yănjīng” yang artinya "mata", di sini fonetik dari karakter “睛” tertulis “jīng” dalam nada kesatu. Sedangkan fonetik dari “头发” tertulis "tóufă" yang artinya "rambut", di sini fonetik dari karakter “发” tertulis “fă” dalam nada ketiga. Menurut Pan dan Chen (1995 : 1021, 877), fonetik dari “眼睛” adalah “yănjing” yang artinya "mata", fonetik dari karakter “睛” tertulis dalam nada ringan. Sedangkan fonetik dari “头发” adalah “tóufa” yang artinya "rambut", fonetik dari karakter “发” tertulis dalam nada ringan. Oleh sebab itu, penulisan fonetik yang benar adalah sebagai berikut:

。。有小小的眼睛, 有长长的头发。

... yǒu xiăoxiao de yănjing, yǒu chángchang de tóufa.

\section{Halaman 36}

\section{她是谁?}

Tā shì shuì?

Siapa dia?

Fonetik dari karakter “谁” tertulis “shù”" dalam nada keempat. Menurut Pan dan Chen (1995 : 809), fonetik dari karakter “谁” adalah "shéi" dalam nada kedua atau "shuî" dalam nada kedua juga yang artinya "siapa".
Oleh sebab itu, penulisan fonetik yang benar adalah sebagai berikut:

她是谁?

Tā shì shéi? atau tā shì shuí?

\section{Halaman 45}

\section{过马路的时候}

Guò mălù de shíhòu

Ketika menyeberang jalan

Ini adalah judul dari pelajaran 8 . Fonetik dari “时候” tertulis “shíhòu”, di sini fonetik dari karakter “候” tertulis “hòu” dalam nada keempat. Menurut Pan dan Chen (1995 : 780), fonetik dari “时候” adalah “shíhou” yang artinya "waktu; saat; ketika", fonetik dari karakter “候” tertulis dalam nada ringan. Oleh sebab itu, penulisan fonetik yang benar adalah sebagai berikut:

过马路的时候

Guò mălù de shíhou

\section{Halaman 46}

。。 , 有一位太太过马路。

..., yǒu yî wèi tàitai guò mălù.

..., ada seorang nyonya menyeberang jalan raya.

Fonetik dari karakter "一” tertulis "y $\overrightarrow{1}$ " dalam nada kesatu. Menurut Cheung (1994 : 61), bila karakter "一" diikuti oleh karakter yang mempunyai nada keempat, maka fonetik dari karakter “一” berubah menjadi nada kedua. Dalam hal ini, karakter “位” tertulis "wèi”" dalam nada keempat, maka fonetik dari karakter "一" seharusnya tertulis "yî" dalam nada kedua. Oleh sebab itu, penulisan fonetik yang benar adalah sebagai berikut:

。。，有一位太太过马路。

..., yǒu yí wèi tàitai guò mălù.

\section{Halaman 72}




\section{汉语难不难?}

Hànyǔ nán bù nán?

Bahasa Mandarin susah tidak?

Fonetik dari karakter “不” tertulis "bù" dalam nada keempat. Menurut Cheung (1994 : 39), fonetik dari karakter “不” dalam pertanyaan positif-negatif menjadi nada ringan. Oleh sebab itu, penulisan fonetik yang benar adalah sebagai berikut:

汉语难不难?

Hànyǔ nán bu nán?

\section{Halaman 73}

\section{汉语不难。}

Hànyǔ bù nàn.

Bahasa Mandarin tidak susah.

Fonetik dari karakter “难” tertulis "nàn" dalam nada keempat. Menurut Pan dan Chen (1995 : 610-611), fonetik dari karakter “难” ada dua yaitu "nán" atau "nàn". Bila fonetik dari karakter "难” dibaca "nán” dalam nada kedua, maka artinya adalah "susah; sulit; sukar". Sedangkan, bila fonetik dari karakter “难” dibaca "nàn" dalam nada keempat, maka artinya adalah "celaka; malapetaka; musibah". Oleh sebab itu, penulisan fonetik yang benar adalah sebagai berikut: 汉语不难。

Hànyǔ bù nán.

\section{Halaman 92}

。。，还有操场。

..., háiyǒu cāocháng.

..., dan ada lapangan olahraga.

Fonetik dari “操场” tertulis "cāocháng", di sini fonetik dari karakter “场” tertulis "cháng" dalam nada kedua. Menurut Pan dan Chen (1995 : 83), fonetik dari “操场” adalah "cāochăng" yang artinya "lapangan main; lapangan olah raga", dimana fonetik dari karakter “场” tertulis dalam nada ketiga. Oleh sebab itu, penulisan fonetik yang benar adalah sebagai berikut:

。。，还有操场。

..., háiyǒu cāochăng.

\section{Halaman 116}

\section{也不喜欢看电影。}

Yě bú xǔuhan kàn diànyǐng. Juga tidak suka menonton film.

Fonetik dari “喜欢” tertulis "xǐuhan". Menurut Pan dan Chen (1995 : 942), fonetik dari “喜欢” adalah "xǐhuan” yang artinya "suka; cinta; gemar". Sedangkan, menurut Cheung (1994 : 7), fonetik dari karakter “不” bila berada didepan karakter yang mempunyai nada ketiga, maka fonetik dari karakter “不” adalah "bù” dalam nada keempat. Dalam hal ini fonetik dari karakter “喜” adalah "xî" dalam nada ketiga, maka fonetik dari karakter “不” menjadi "bù" dalam nada keempat. Oleh sebab itu, penulisan fonetik yang benar adalah sebagai berikut:

也不喜欢看电影。

Yě bù xǐhuan kàn diànyı̌ng.

\section{Halaman 117}

\section{我喜欢新闻节目。}

Wǒ xǐhuan xīnwèn jiémù.

Saya suka acara berita.

Fonetik dari “新闻” tertulis “xīnwèn", dimana fonetik dari karakter “闻” tertulis "wèn" dalam nada keempat. Menurut Pan dan Chen (1995：984), fonetik dari “新闻” adalah "xīnwén" yang artinya adalah "berita", di sini fonetik dari karakter “闻” tertulis "wén" dalam nada kedua. Oleh sebab itu, 
penulisan fonetik yang benar adalah sebagai berikut:

我喜欢新闻节目。

Wǒ xǐhuan xīnwén jiémù.

\section{KESIMPULAN}

Penulis menyimpulkan adanya kesalahan-kesalahan fonetik yang ada dalam buku yang berjudul "Percakapan Bahasa Mandarin Sehari-hari Lengkap Langsung Bisa", hal tersebut mungkin terjadi karena penulis dari buku tersebut kurang teliti terhadap fonetik-fonetik dari karakterkarakter Bahasa Mandarin. Oleh sebab itu, seorang penulis buku Bahasa Mandarin perlu teliti terhadap fonetik-fonetik dari karakterkarakter Bahasa Mandarin, sehingga buku yang ditulis dapat memberikan model pembelajaran bahasa yang baik dan benar terhadap para pembacanya.

\section{REFERENSI}

Cheung, H. S. (1994). A Practical Chinese Grammar. Hong Kong: The Chinese University Press.

Huang, B. dan Liao, X. (2004). Xiandai Hanyu (zengding san ban) shang ce. Beijing: Gaodeng Jiaoyu Chubanshe.

Kang, Y. dan Lai, S. (2000). Hanyu Huihua 301 ju. Beijing: Beijing Yuyan Wenhua Daxue Chubanshe.

Li, D. dan Li, G. (1999). Xiandai Hanyu Jiaocheng Duxie Keben di yi ce. Beijing: Beijing Yuyan Wenhua Daxue Chubanshe.

Pan, Z. dan Chen, W. (1995). Hanyu Yindunixiyayu Dacidian. Beijing: Waiwen Chubanshe.

Ross, C. dan Jing-heng, S., M. (2006). Modern Mandarin Chinese Grammar. Oxon: Routledge.

Shendingweiyuanhui (2012). Xiandai Hanyu Cidian. Beijing: Shangwu Yinshuguan. 